University of Nebraska - Lincoln

DigitalCommons@University of Nebraska - Lincoln

Faculty Papers and Publications in Animal

Science

Animal Science Department

2005

\title{
Consumer Sensory Acceptance and Value of Domestic, Canadian, and Australian Grass-Fed Beef Steaks
}

\author{
B. M. Sitz \\ University of Nebraska-Lincoln \\ Chris R. Calkins \\ University of Nebraska-Lincoln, ccalkins1@unl.edu \\ D. M. Feuz \\ University of Nebraska-Lincoln \\ W. J. Umberger \\ University of Nebraska-Lincoln \\ Kent M. Eskridge \\ University of Nebraska-Lincoln, keskridge1@unl.edu
}

Follow this and additional works at: https://digitalcommons.unl.edu/animalscifacpub

Part of the Animal Sciences Commons

Sitz, B. M.; Calkins, Chris R.; Feuz, D. M.; Umberger, W. J.; and Eskridge, Kent M., "Consumer Sensory Acceptance and Value of Domestic, Canadian, and Australian Grass-Fed Beef Steaks" (2005). Faculty Papers and Publications in Animal Science. 581.

https://digitalcommons.unl.edu/animalscifacpub/581

This Article is brought to you for free and open access by the Animal Science Department at DigitalCommons@University of Nebraska - Lincoln. It has been accepted for inclusion in Faculty Papers and Publications in Animal Science by an authorized administrator of DigitalCommons@University of Nebraska - Lincoln. 


\title{
Consumer sensory acceptance and value of domestic, Canadian, and Australian grass-fed beef steaks ${ }^{1}$
}

\author{
B. M. Sitz, C. R. Calkins, ${ }^{2}$ D. M. Feuz, W. J. Umberger, and K. M. Eskridge
}

Animal Science Department, University of Nebraska, Lincoln 68583-0908

\begin{abstract}
To determine US consumer acceptance and value of beef from various countries, 24 taste panels of consumers ( $\mathrm{n}=273$ consumers) were conducted in Denver and Chicago. Two pairs of strip steaks were evaluated for flavor, juiciness, tenderness, and overall acceptability on eight-point hedonic scales. One pair consisted of an Australian grass-fed strip steak and a domestic strip steak, whereas the other pair included Canadian and domestic strip steaks. The pairs were matched to similar Warner-Bratzler shear values and marbling scores to decrease variation associated with tenderness and juiciness. A variation of the Vickery auction was used to obtain silent, sealed bids on steaks $(0.45 \mathrm{~kg})$ from the same strip loins sampled in the taste panel. Consumers gave higher $(P<0.001)$ scores for flavor, juiciness, tenderness, and overall acceptability for domestic steaks compared with Australian grass-
\end{abstract}

fed steaks. Domestic steaks averaged $\$ 3.68 / 0.45 \mathrm{~kg}$, whereas consumers placed an average value of $\$ 2.48$ / $0.45 \mathrm{~kg}$ on Australian grass-fed steaks $(P<0.001)$. Consumers rated Canadian steaks numerically lower for juiciness $(P=0.09)$ and lower $(P<0.005)$ for flavor, tenderness, and overall acceptability than domestic samples. Consumers placed an average value of $\$ 3.95 /$ $0.45 \mathrm{~kg}$ for domestic steaks and $\$ 3.57 / 0.45 \mathrm{~kg}$ for Canadian steaks $(P<0.01)$. Consumers $(19.0 \%)$ who preferred Australian grass-fed steaks over domestic steaks paid $\$ 1.38 / 0.45 \mathrm{~kg}$ more $(P<0.001)$, whereas consumers $(29.3 \%)$ who favored the Canadian steaks over the domestic steaks paid $\$ 1.37 / 0.45 \mathrm{~kg}$ more $(P<0.001)$ for the Canadian steaks. A majority of US consumers seem to be accustomed to the taste of domestic beef and prefer domestic steaks to beef from Australia grass-fed and Canadian beef.

Key Words: Beef, Country of Origin, Grain-Fed, Grass-Fed, Palatability

(2005 American Society of Animal Science. All rights reserved.

J. Anim. Sci. 2005. 83:2863-2868

\section{Introduction}

The United States is well known for producing beef from young, corn-fed cattle. In contrast, Canada's climate is better suited for producing barley, which is frequently used as the grain base in cattle finishing diets. Australia produces large quantities of lean, grassfed beef. More importantly, cattle diets have been shown to affect the sensory properties of beef. Davis et al. (1981) and Berry et al. (1988) reported that sensory ratings for tenderness were higher for grain-fed beef than for forage-finished beef. In some cases, flavor desirability scores were more favorable and off-flavor notes were less common in grain-fed beef (Davis et al., 1981; Larick et al., 1987; Berry et al., 1988). Jeremiah et al. (1998) found that a greater proportion of steaks from

\footnotetext{
${ }^{1}$ Published as Paper No. 14806, Journal Series, Nebraska Agric. Res. Div., Univ. Nebraska, Lincoln 68583-0908.

${ }^{2}$ Correspondence: A213 Animal Science (phone: 402-472-6314; fax: 402-472-6362; e-mail: ccalkins1@unl.edu).

Received November 3, 2004.

Accepted August 15, 2005.
}

barley-fed steers were noted to possess livery, bloody, and metallic aftertastes than steaks from corn-fed cattle. In contrast, others (McCurdy et al., 1981; Miller et al., 1996) failed to detect differences among barley- and corn-finished beef.

Recently, Killinger et al. (2004a,b) observed that consumers were willing to pay a premium for beef that possessed the flavor characteristics they desired, which included grain-fed domestic beef compared with grassfed Argentinian beef (Killinger et al., 2004a) and beef with Moderate or Modest marbling compared with slight marbling (Killinger et al., 2004b). The present research was conducted to determine whether there were sensory and value differences among US consumers for grass-fed Australian, grain-fed Canadian, and domestic, corn-fed beef.

\section{Materials and Methods}

Sensory evaluations were conducted in Denver, CO and Chicago, IL. Twelve taste panels were completed in each city during summer 2002; 132 consumers participated in Denver, and 141 consumers participated in 
Chicago. Four panels (12 consumers per panel) were scheduled for three consecutive days in each city. The data were part of a larger study that included other comparisons (Sitz, 2003). Panelists tasted a total of four pairs of beef strip steak samples. Two of the pairs were domestic vs. Canadian and domestic vs. grass-fed Australian beef.

\section{Steak Preparation}

Canadian (AAA quality grade; $\mathrm{n}=39$ ) and grass-fed Australian strip loins $(\mathrm{n}=30)$ were purchased from a boxed beef importer, whereas domestic strip loins $(\mathrm{n}=$ 76) were purchased from a national meat processor. Steaks were cut from the strip loin using an electric band saw to a thickness of $2.54 \mathrm{~cm}$. The steaks were numbered from anterior (rib end) to posterior (loin end); wrapped in white butcher paper; labeled with a random, three-digit number; and frozen in a $-20^{\circ} \mathrm{C}$ freezer for up to 9 mo.

\section{Chemical Analyses}

Marbling score of the strip loin was determined from the most anterior steak (steak 1). The subcutaneous fat over the LM was removed, and the lean was cubed, immersed in liquid $\mathrm{N}_{2}$, and pulverized in a Waring blender (Dynamics Corporation of America, New Hartford, CT). Ash and moisture content were analyzed using a LECO thermogravimetric analyzer (LECO Corp., St. Joseph, MO) in duplicate samples. Lipid content was measured by the Soxlet method using anhydrous ether on duplicate samples (AOAC, 1990).

\section{Warner-Bratzler Shear Force Determination}

The second steak (steak 2) from the anterior end of the loin was used to determine Warner-Bratzler shear values. The steaks were frozen in a $-22^{\circ} \mathrm{C}$ freezer and were thawed for $24 \mathrm{~h}$ in a $4^{\circ} \mathrm{C}$ cooler. The steaks were trimmed of external fat, cooked on Farberware open hearth broilers (Farberware Co., Bronx, NY) to an internal temperature of $35^{\circ} \mathrm{C}$, turned, and broiled to a final temperature of $70^{\circ} \mathrm{C}$. Temperature was measured intermittently at the geometric center of the steak using a digital thermometer and thermocouple (Omega Engineering, Inc., Stamford, CT). The steaks were cooled in a $4^{\circ} \mathrm{C}$ cooler for a minimum of $1 \mathrm{~h}$. After cooling, 10 to 12 cores (1.27-cm diameter) were removed parallel to the longitudinal orientation of the muscle fibers from the LM using a drill press (Delta International Machinery Corp., Pittsburgh, PA). Warner-Bratzler shear force was measured the same day as coring. Shear force was measured on at least eight cores from each steak using an Instron Universal Testing Machine (Instron Corp., Canton, MA) with a Warner-Bratzler shear force attachment. Irregularly shaped cores were not sheared. A 500-kg load cell was used with a crosshead speed of $250 \mathrm{~mm} / \mathrm{min}$.

\section{Pairing of Strip Loins}

Two pairs of loins were matched for each taste panel: 1) domestic and Australian, grass-fed strip loins and 2) domestic and Canadian AAA strip loins. Separate strip loins were used for each sensory evaluation session. For each pair, loins within a marbling score were matched as closely as possible for Warner-Bratzler shear values. A total of 48 domestic, 24 Australian, and 24 Canadian loins were evaluated by the panels.

The aging period of the strip loins varied from each category. The aging period for this study was defined as the time from the vacuum-packaging date to the date the steaks were frozen for storage. Domestic strip loins were aged for 8 to $11 \mathrm{~d}$, simulating an average storage time for fresh beef from the packing plant to the meat counter. The Australian grass-fed strip loins were aged the longest (67 to $73 \mathrm{~d}$ ), whereas the Canadian strip loins were aged for $24 \mathrm{~d}$.

\section{Preparation of Taste Panel Samples}

Taste panel samples were prepared as the panelists arrived at the host facility. The third and fourth steaks from the anterior end of the strip loin were used for taste panel samples. The steaks were shipped frozen to the host facilities and thawed in a $4^{\circ} \mathrm{C}$ refrigerator for $24 \mathrm{~h}$ before taste panels. Steaks were trimmed of excess fat and cooked to an internal temperature of $70^{\circ} \mathrm{C}$ on Farberware open hearth broilers. After cooking, steaks were removed from the broilers and wrapped in aluminum foil for $5 \mathrm{~min}$ or less. Then, steaks were cut into 1 -cm $\times 2$-cm cubes that were wrapped in aluminum packets, labeled with the appropriate identification number, and placed into a double broiler. Samples were held at approximately $40^{\circ} \mathrm{C}$ for $\leq 20 \mathrm{~min}$ until served. A single cube of steak was placed onto a plate, labeled with the identification number, and served to the panelist. Water and unsalted saltine crackers were provided to the panelists to cleanse their palates between samples.

\section{Screening of Panelists}

Panelists were screened by employees of the host facilities via telephone or through a written survey. To qualify for the taste panel, consumers had to be the primary grocery shopper of the household, be between the ages of 19 and 59, have no food allergies, and be willing to consume beef. Consumers were disqualified if they or their immediate families worked for the meat or cattle industry, marketing, or advertising agencies. A survey of demographic information, eating preferences, purchasing behavior, and a consent form were mailed to panelists to be completed before the taste panel.

On arrival at the host facility, panelists were asked to complete a meat knowledge survey, as well as any incomplete paperwork. Panelists were assigned random three-digit numbers for identification. Panelists were paid $\$ 50$ in advance for their participation, which 
they could choose to use when their bids were successful in the taste panel.

\section{Auction Procedures}

The panelists were seated in a conference room, and the moderator read the written dialogue explaining the auction procedure. Panelists bought steaks taken from the same strip loin as the sample tasted. A reference price of $\$ 7.00$ /pound was given to panelists for a Choice strip loin steak before conducting three nonbinding practice auctions. Panelists were not required to bid; however, if panelists chose to bid and won a nonpractice auction, the panelist would pay from the participation payment. One steak from each pair would be a binding auction, although panelists did not know which steaks were to be sold until the completion of the taste panel. Panelists tasted a pair of samples and then submitted silent, sealed bids on both steaks.

A variation (the number of winners per sample was assigned randomly) of the Vickery (uniform-price) auction was used. Price auction " $\mathrm{n}$ " determined the purchase price [the amount the winner(s) paid] for the auction $(\mathrm{n}=2,3$, or 4$)$. In a second price auction, the second highest bid was the purchase price the highest bidder paid for the steak. For a third price auction, the third highest bid set the purchase price for the steak, and the highest and second highest bidders would only pay the price of the third highest bid. The fourth price auction resulted in three winners.

Because the winners of the auctions do not pay the amount they bid, it is in the best interests of consumers to bid the exact amount they are willing to pay for a sample (Vickery, 1961). Consumers who underbid risk losing the auction, whereas those who overbid risk overpaying for the item. The best strategy is to bid the highest value they are willing to pay for each item (Menkhaus et al., 1990).

Three practice auctions were conducted to familiarize the panelists with the auction procedure. Coppinger et al. (1980) reported that bids in Vickery auctions stabilize over several bidding sequences. Panelists placed hypothetical bids after visually evaluating packages of beef strip steaks containing different amounts of labeling information (Umberger et al., 2003). The third practice auction was a warm-up sensory sample to familiarize panelists with the sensory evaluation process and flavor, juiciness, and tenderness traits. If a panelist chose to bid $\$ 0$ for a sample, the panelist was asked to provide a written explanation of why he or she chose not to bid.

\section{Tasting and Bidding on Samples}

Panelists were placed at individual tasting booths or tables to evaluate sensory traits of the samples. The first sample of the pair was served on a $15-\mathrm{cm}$ paper plate identified with the sample number. Panelists evaluated the first sample for sensory traits using an eight-point hedonic scale ( 1 = extremely undesirable to $8=$ extremely desirable). The second sample of the pair was served on a $15-\mathrm{cm}$ paper plate labeled with the sample identification number and evaluated for sensory traits. After both samples were tasted, panelists bid on the samples. The value of each steak was placed on an individual bid sheet that was labeled with the sample's identification number. The panelists' bids were collected, and the purchase price of the samples was determined. Slips announced the purchase price, potential winners (one sample auction was binding, the other sample was not sold), or if the panelists did not win an auction. The procedure was repeated for the second pair of samples.

To avoid biasing the bids, the auctions that were binding were announced after all of the samples had been tasted and slips had been distributed to the panelists. Panelists who did not win any auction were announced, and these panelists were free to leave. The panelists who had won auctions stayed to purchase their steaks. Change was given if needed, and the panelists received their steaks and a receipt for their purchase.

\section{Statistical Analyses}

All 273 panelists were included in the sensory evaluation portion of the analysis. If a panelist bid $\$ 0.00 / 0.45$ $\mathrm{kg}$ for all samples, the panelist was removed from the auction portion of the analysis. Forty panelists were deleted from the dataset because they were not willing to purchase samples, leaving 233 panelists for the auction portion of the analysis.

Differences in chemical analysis, sensory panel evaluation, and auction data were analyzed using the Mixed procedure of SAS (SAS Inst., Inc., Cary, NC). Data from the meat knowledge survey and the demographic survey were analyzed using a two-way contingency table with the FREQ procedure of SAS.

A split-plot analysis was used for the Australian and Canadian pairs in the sensory evaluation. Pair (Australian vs. domestic or Canadian vs. domestic) was the whole-plot factor, whereas treatment (Australian, Canadian, or domestic) was the split-plot factor, which was nested within pair. In the ANOVA, factors included city $(\mathrm{C})$, evaluation session $(\mathrm{S})$, panelist $(\mathrm{P})$, pair (A), and treatment $(\mathrm{T})$. The model contained the fixed effects of $\mathrm{C}, \mathrm{S}(\mathrm{C}), \mathrm{P}(\mathrm{S} \times \mathrm{C}) \mathrm{A}, \mathrm{A} \times \mathrm{C}, \mathrm{A} \times \mathrm{S}(\mathrm{C}), \mathrm{A} \times \mathrm{P}(\mathrm{S} \times \mathrm{C})$, $\mathrm{T}(\mathrm{P}), \mathrm{C} \times \mathrm{T}(\mathrm{A})$, and $\mathrm{T} \times \mathrm{A} \times \mathrm{S}(\mathrm{C})$; $\mathrm{P}$ was considered as a random effect.

For the proximate analysis (ash, moisture, fat, protein, and marbling) and Warner-Bratzler shear force analysis, pair was the whole-plot factor, whereas treatment was the split-plot factor. Fixed effects included in the ANOVA model were $\mathrm{C}, \mathrm{S}(\mathrm{C}), \mathrm{A}, \mathrm{A} \times \mathrm{C}, \mathrm{P} \times \mathrm{S}(\mathrm{C})$, $\mathrm{T}(\mathrm{A}), \mathrm{C} \times \mathrm{T}(\mathrm{A})$, and $\mathrm{T} \times \mathrm{A} \times \mathrm{S}(\mathrm{C})$.

Overall acceptability ratings were used to categorize the consumers into three groups: 1) consumers who preferred the Australian (or Canadian) sample in a 
Table 1. Taste panel evaluation ratings $(n=273)$ and auction bids $(n=233)$ for domestic, Australian, and Canadian strip loin steaks matched by shear force and marblinga,b

\begin{tabular}{|c|c|c|c|c|c|}
\hline Pair & Flavor $^{\mathrm{a}}$ & Juiciness $^{a}$ & Tenderness ${ }^{\mathrm{a}}$ & $\begin{array}{c}\text { Overall } \\
\text { acceptability }^{\mathrm{a}}\end{array}$ & $\begin{array}{c}\text { Bid, } \$ / 0.45 \\
\mathrm{~kg}^{\mathrm{b}}\end{array}$ \\
\hline Australian & 4.58 & 4.49 & 4.38 & 4.34 & 2.48 \\
\hline Domestic & 5.67 & 5.20 & 5.17 & 5.37 & 3.68 \\
\hline Difference & -1.09 & -0.71 & -0.79 & -1.03 & -1.20 \\
\hline $\mathrm{SE}$ & 0.082 & 0.082 & 0.084 & 0.080 & 0.148 \\
\hline$P$-value & 0.001 & 0.001 & 0.001 & 0.001 & 0.001 \\
\hline Canadian & 5.64 & 5.36 & 5.37 & 5.49 & 3.57 \\
\hline Domestic & 5.94 & 5.53 & 5.67 & 5.79 & 3.95 \\
\hline Difference & -0.30 & -0.17 & -0.30 & -0.30 & -0.38 \\
\hline $\mathrm{SE}$ & 0.082 & 0.082 & 0.084 & 0.080 & 0.148 \\
\hline$P$-value & 0.003 & 0.092 & 0.003 & 0.001 & 0.012 \\
\hline
\end{tabular}

${ }^{\mathrm{a}} 1$ = extremely undesirable, 2 = very undesirable, 3 = moderately undesirable, $4=$ slightly undesirable, 5 = slightly desirable, $6=$ moderately desirable, $7=$ very desirable, and $8=$ extremely desirable.

${ }^{\mathrm{b}}$ Consumers who bid $\$ 0$ for every sample were removed from the bid data set.

pair, 2) consumers who preferred the domestic sample in a pair, or 3) consumers who were indifferent in their preference. Auction data were analyzed using the three acceptability groups as a split-plot; acceptability group was the whole-plot, and sample (domestic vs. Australian grass-fed or domestic vs. Canadian) was the splitplot. Random effects were $\mathrm{P}$ and $\mathrm{S}$, whereas fixed effects included acceptability group (G), sample (B), C, S(C), $\mathrm{P}(\mathrm{S} \times \mathrm{C}), \mathrm{G} \times \mathrm{L}, \mathrm{G} \times \mathrm{S}(\mathrm{C}), \mathrm{B} \times \mathrm{C}, \mathrm{B} \times \mathrm{S}(\mathrm{C}), \mathrm{B} \times \mathrm{P}(\mathrm{S} \times$ $\mathrm{G}), \mathrm{B} \times \mathrm{G}, \mathrm{B} \times \mathrm{G} \times \mathrm{C}$, and $\mathrm{B} \times \mathrm{G} \times \mathrm{S}(\mathrm{C})$. In all analyses, least squares means were statistically separated using the PDIFF option when the $F$-test was significant $(P$ $\leq 0.05)$.

\section{Results and Discussion}

Consumers rated domestic beef higher $(P<0.001)$ for flavor, juiciness, tenderness, and overall acceptability than Australian grass-fed beef (Table 1). Consumers placed a higher $(P<0.001)$ value on domestic samples than on Australian samples (Table 1). Because the samples in a pair were matched by tenderness, Warner-

Table 2. Warner-Bratzler shear force (WBSF) value, marbling scores, and quality grade for Australian, domestic, and Canadian strip loin samples ${ }^{\mathrm{a}, \mathrm{b}}$

\begin{tabular}{lccl}
\hline \hline Pair & WBSF, kg & Marbling $^{\mathrm{a}}$ & $\begin{array}{c}\text { Quality } \\
\text { grade }^{\mathrm{b}}\end{array}$ \\
\hline Australian & 3.61 & 183.33 & 3.32 \\
Domestic & 3.64 & 229.58 & 3.75 \\
SE & 0.024 & 10.420 & 0.110 \\
$P$-value & 0.320 & 0.003 & 0.010 \\
Canadian & 2.95 & 282.08 & 4.37 \\
Domestic & 2.97 & 320.83 & 4.75 \\
SE & 0.024 & 10.420 & 0.110 \\
$P$-value & 0.596 & 0.010 & 0.021 \\
\hline
\end{tabular}

${ }^{\mathrm{a}} 0$ to 99 = Slight, 100 to 199 = Small, 200 to 299 = Modest, 300 to $399=$ Moderate, and 400 to $499=$ Slightly Abundant.

${ }^{\mathrm{b}} 1=$ low Select, 2 = high Select, 3 = low Choice, 4 = average Choice, and $5=$ high Choice.
Bratzler shear values did not differ $(P=0.320)$ between Australian and domestic samples (Table 2). Marbling scores (Table 2$)$ differed $(P<0.003)$ between Australian grass-fed $\left(\mathrm{Small}^{83}\right)$ and domestic pairs $\left(\right.$ Modest $\left.^{29}\right)$; however, Australian grass-fed and domestic samples were within the same quality grade of low Choice, and differed by only $15 \%$ of one quality grade (Table 2 ). Even though marbling score was matched as closely as possible, the average percentage of fat content for Australian samples was $2.46 \%$ less $(P<0.001)$ than the domestic pair, which possibly influenced the higher juiciness scores for domestic samples (Table 3). Australian samples had greater ash $(P<0.001)$ and moisture contents than did domestic samples (Table 3).

The largest sensory difference between the Australian and domestic pair was flavor. A flavor difference of one unit favoring domestic samples was observed (Table 1). Consumer comments frequently included reference to off-flavors and off-odors, possibly because of longer aging periods for the Australian grass-fed samples. Cattle diet also influences the flavor of beef. Xiong et al. (1996) noted grassy flavors and off-flavors were significantly more pronounced in grass-fed steers than in grain-supplemented steers. Higher beef flavor intensity was observed for corn-fed steers than for steers

Table 3. Proximate analysis of domestic, Australian grassfed, and Canadian strip loin taste panel steaks

\begin{tabular}{llccc}
\hline \hline Pair & Ash, \% & Moisture, \% & Fat, \% & Protein, \% \\
\hline Australian & 1.68 & 72.47 & 6.12 & 19.74 \\
Domestic & 1.13 & 70.61 & 8.58 & 19.68 \\
Difference & 0.55 & 1.86 & -2.46 & 0.06 \\
SE & 0.026 & 0.331 & 0.336 & 0.194 \\
$P$-value & 0.001 & 0.001 & 0.001 & 0.831 \\
Canadian & 1.65 & 70.62 & 8.82 & 18.92 \\
Domestic & 1.07 & 69.14 & 10.25 & 19.54 \\
Difference & 0.58 & 1.48 & -1.43 & -0.62 \\
SE & 0.026 & 0.331 & 0.336 & 0.194 \\
$P$-value & 0.001 & 0.003 & 0.004 & 0.028 \\
\hline
\end{tabular}


finished on grass (Berry et al., 1988). Similar to present results, Killinger et al. (2004b) found that the flavor of domestic beef was favored by consumers in a study comparing domestic with Argentine grass-fed beef of similar marbling and shear force.

Aging also influences the incidence of off-flavors in grass-fed beef (Campo et al., 1999). Aging the beef for $10 \mathrm{~d}$ caused the frequency of off-flavors to nearly double (Xiong et al., 1996). Because the Australian samples were vacuum-aged for 67 to $73 \mathrm{~d}$ during shipping and storage, off-flavors could have developed. Domestic samples were aged for only 8 to $11 \mathrm{~d}$ to simulate the time between slaughtering and retail display of domestic beef; therefore, the superior flavor scores for domestic beef could be due, in part, to shorter aging times.

Tenderness ratings for domestic samples were higher $(P<0.001)$ than Australian samples, possibly influenced by higher $(P<0.001)$ flavor scores (Table 1$)$. Although Warner-Bratzler shear values did not differ $(P=$ 0.320 ) for samples in the pair, consumers found Australian samples to be tougher.

Domestic beef flavor, tenderness, and overall acceptability scores were higher $(P<0.005)$ than Canadian beef scores (Table 1). The difference in value between domestic and Canadian samples was not as great as between domestic and Australian samples. Consumers bid more $(P<0.01)$ for domestic beef than for Canadian beef (Table 1). Canadian samples were higher $(P \leq$ $0.003)$ in ash and moisture and lower $(P \leq 0.028)$ in fat and protein (Table 3). Although average marbling scores were higher in domestic samples than in Canadian samples (Moderate ${ }^{21}$ vs. Modest ${ }^{82}$ ), the quality grades were similar for domestic and Canadian samples (average Choice; Table 2).

Flavor differences $(P<0.005)$ between domestic and Canadian beef agree with results of Jeremiah et al. (1998), in which barley-fed beef was rated as having more undesirable flavor than corn-fed beef. The higher flavor score (5.94) of the domestic beef compared with the lower flavor score (5.64) of the Canadian beef contradicts results from Miller et al. (1996), who found no flavor differences in beef from cattle fed corn, corn/ barley, or barley-based diets. The flavor difference could be due to the higher fat content of the domestic samples (Table 3). Killinger et al. (2004a) reported flavor differences of similar magnitude when marbling differed by two full marbling scores (Slight vs. Modest or Moderate), which was reflected by a $2.76 \%$ difference in fat percentage.

Sensory panels in the study by Jeremiah et al. (1998) perceived more connective tissue in steaks from corn/ corn silage-fed steers than barley/barley silage-fed steers; however, Miller et al. (1996) reported similar Warner-Bratzler shear values, muscle fiber tenderness, amount of connective tissue, and overall tenderness ratings for steers fed a corn-based, barley-based, or corn/barley-based diet. In the current study, domestic samples were rated more tender $(P<0.005)$ than Canadian samples, although Warner-Bratzler shear values
Table 4. Consumer bids $(\$ / 0.45 \mathrm{~kg})$ based on overall preference placed on Australian grass-fed or domestic steaks

\begin{tabular}{lccc}
\hline \hline & \multicolumn{3}{c}{ Preference } \\
\cline { 2 - 4 } Trait & Australian & Domestic & Neither \\
\hline Sensory panelist $^{\mathrm{a}}$ & 52 & 176 & 45 \\
Bidding consumer $^{\mathrm{b}}$ & 43 & 154 & 36 \\
Australian & $\$ 3.53$ & $\$ 2.03$ & $\$ 3.12$ \\
Domestic & $\$ 2.15$ & $\$ 4.26$ & $\$ 3.05$ \\
Difference & 1.38 & -2.23 & 0.07 \\
$P$-value & 0.001 & 0.001 & 0.850 \\
\hline
\end{tabular}

${ }^{\mathrm{a} C o n s u m e r s}(\mathrm{n}=273)$ who evaluated sensory traits for the pair of samples.

${ }^{b}$ Consumers $(n=40)$ who bid $\$ 0$ for all samples were removed from the bid data set.

(Table 3) did not differ $(P=0.596)$ between Canadian samples and domestic samples (Table 3 ).

Consumer preference was defined as the highest overall acceptability score within a pair. Although the majority of consumers preferred domestic to Australian grass-fed or Canadian beef, some consumers preferred the flavor of the Australian grass-fed or the Canadian samples (Tables 4 and 5). More consumers favored domestic (64.5\%) vs. Australian grass-fed (19.0\%) beef. The remaining consumers (16.5\%) did not prefer either sample. The percentage of consumers with no preference between Canadian and domestic samples was $26.7 \%$, whereas $44 \%$ of consumers preferred the domestic samples, and $29.3 \%$ favored the Canadian samples.

Consumers were willing to pay more $(P<0.001)$ for their preference (Tables 4 and 5). Consumers who preferred Australian grass-fed samples bid $\$ 1.38 / 0.45 \mathrm{~kg}$ more for their preference, whereas consumers who preferred the domestic samples bid $\$ 2.23 / 0.45 \mathrm{~kg}$ more for the domestic samples. Consumers with no preference for Australian grass-fed or domestic samples bid similar amounts for the samples (Table 4).

In the Canadian and domestic pair, consumers who preferred the Canadian samples bid $\$ 1.37 / 0.45 \mathrm{~kg}$ more $(P<0.001)$ for their preference (Table 5$)$. Consumers

Table 5. Consumers' bids $(\$ / 0.45 \mathrm{~kg})$ based on overall preference placed on Canadian or domestic steaks

\begin{tabular}{lccc}
\hline \hline & \multicolumn{3}{c}{ Preference } \\
\cline { 2 - 4 } Item & Canadian & Domestic & Neither \\
\hline Sensory panelist $^{\mathrm{a}}$ & 80 & 120 & 73 \\
Bidding consumer $^{\mathrm{b}}$ & 72 & 102 & 59 \\
Canadian & $\$ 4.57$ & $\$ 2.85$ & $\$ 3.67$ \\
Domestic & $\$ 3.20$ & $\$ 4.48$ & $\$ 3.92$ \\
Difference & 1.37 & -1.63 & -0.25 \\
$P$-value & 0.001 & 0.001 & 0.288 \\
\hline
\end{tabular}

${ }^{\mathrm{a}}$ Consumers $(\mathrm{n}=273)$ who evaluated sensory traits for the pair of samples.

${ }^{b}$ Consumers $(n=40)$ who bid $\$ 0$ for all samples were removed from the bid data set. 
favoring the domestic samples paid $\$ 1.67 / 0.45 \mathrm{~kg}$ more $(P<0.001)$ for their preference. Although the difference was not statistically significant, consumers who preferred the samples equally bid $\$ 0.25 / 0.45 \mathrm{~kg}$ more ( $P=$ 0.288 ) for the domestic samples than for the Canadian samples.

Consumers in the United States favor domestic beef over Australian grass-fed or Canadian beef. Overall acceptability of domestic samples was rated significantly higher than for Australian samples and Canadian samples. Different feeding regimens, various aging periods, and/or different cattle breeds may affect the flavor and overall acceptability of Australian grass-fed and Canadian samples. Consumers also placed a higher value on domestic samples than on Australian and $\mathrm{Ca}$ nadian samples. Because a steady supply of corn-fed beef is available to most consumers in the United States, consumers might have become accustomed to the flavor of corn-fed beef and therefore prefer it.

\section{Implications}

The majority of US consumers preferred domestic beef over Australian grass-fed and Canadian beef. Nonetheless, a small proportion of US consumers preferred the imported product and was willing to pay more for these samples. Thus, a niche market for Australian grass-fed or Canadian beef may be feasible in the United States.

\section{Literature Cited}

AOAC. 1990. Official Methods of Analysis, 15th ed. Assoc. Off. Anal. Chem., Arlington, VA.

Berry, B. W., K. F. Leddy, J. Bond, T. S. Rumsey, and A. C. Hammond. 1988. Effect of silage diets and electrical stimulation on the palatability, cooking and $\mathrm{pH}$ characteristics of beef loin steaks. J. Anim. Sci. 66:892-900.

Campo, M. M., C. Sanudo, B. Panea, P. Alberti, and P. Santolaria. 1999. Breed type and ageing time effects on sensory characteristics of beef strip loin steaks. Meat Sci. 51:383-390.
Coppinger, V. M., V. L. Smith, and J. A. Titus. 1980. Incentives and behavior in English, Dutch, and sealed-bid auctions. Econ. Inq. 18:1-22.

Davis, G. W., A. B. Cole, W. R. Backus, and S. L. Melton. 1981. Effect of electrical stimulation on carcass quality and meat palatability of beef from forage and grain-finished steers. J. Anim. Sci. 53:651-657.

Jeremiah, L. E., K. A. Beauchemin, S. D. M. Jones, L. L. Gibson, and L. M. Rode. 1998. The influence of dietary cereal grain source and feed enzymes on the cooking properties and palatability attributes of beef. Can. J. Anim. Sci. 78:271-275.

Killinger, K. M., C. R. Calkins, W. J. Umberger, D. M. Feuz, and K. M. Eskridge. 2004a. Consumer sensory acceptance and value for beef steaks of similar tenderness, but differing in marbling level. J. Anim. Sci. 82:3294-3301.

Killinger, K. M., C. R. Calkins, W. J. Umberger, D. M. Feuz, and K. M. Eskridge. 2004b. A comparison of consumer sensory acceptance and value of domestic beef steaks and steaks from a branded, Argentine beef program. J. Anim. Sci. 82:3302-3307.

Larick, D. K., H. B. Hedrick, M. E. Bailey, J. E. Williams, D. L. Hancock, G. B. Garner, and R. E. Morrow. 1987. Flavor constituents of beef as influenced by forage and grain feeding. J. Food Sci. 52:245-250.

McCurdy, S. M., M. M. Hardy, and E. L. Martin. 1981. Sensory properties of rib and round muscle roasts from two beef breed types on two feeding regimes. J. Food Sci. 46:991-995.

Menkhaus, D. J., R. A. Field, and G. D. Whipple. 1990. Economic value of case ready meats as determined by the consumer. Beef Industry Council Natl. Livest. Meat Board, Chicago, IL.

Miller, M. F., L. C. Rockwell, D. K. Lunt, and G. E. Carstens. 1996. Determination of the flavor attributes of cooked beef from crossbred Angus steers fed corn- or barley-based diets. Meat Sci. 44:235-243.

Sitz, B. M. 2003. Consumer sensory acceptance and value of beef from various aging techniques and countries of origin. M.S. Thesis, Univ. Nebraska, Lincoln.

Umberger, W. J., D. M. Feuz, C. R. Calkins, and B. M. Sitz. 2003. Country-of-origin labeling of beef products: U.S. consumers' perceptions. J. Food Distrib. Res. 34:103-116.

Vickery, W. 1961. Counterspeculation, auctions, and competitive sealed tenders. J. Finance 16:8-37.

Xiong, Y. L., W. G. Moody, S. P. Blanchard, G. Liu, and W. R. Burris. 1996. Postmortem proteolytic and organoleptic changes in hotboned muscle from grass- and grain-fed and zeranol-implanted cattle. Food Res. Int. 29:27-34. 